\title{
Fungal microbiota isolated from healthy pig skin*
}

\author{
Microbiota fúngica isolada da pele de suínos sadios \\ Fabiano Bonfim Carregaro', Andréia Spanamberg', Edna Maria Cavallini Sanches', \\ Juliana Siqueira Argenta', Daniela Isabel Brayer Pereira' ${ }^{1}$, Régis Zanette', Janio Morais Santurio², \\ David Emílio Santos Neves de Barcellos ${ }^{3} \&$ Laerte Ferreiro $^{1}$
}

\begin{abstract}
Background: Researches have been developed to observe the normal microbiota of different animal species. This subject is of major importance for the control of potential infection risks. Fungi can be found in various substrates, foodstuffs (cereals, meat, milk, vegetables) and also in the skin, mucosae, respiratory and gastrointestinal tracts of animals. With the dissemination of immunosuppressive diseases in swine herds over the last years, the number of concomitant diseases caused by opportunist microorganisms is gradually increasing in literature. The objective of this study was to determine the microbiota of pig skin with no apparent lesions.

Materials, Methods and Results: A number of 261 pigs from 11 swine farms located in six municipalities of the State of Rio Grande do Sul, in Southern Brazil, were used for the study, in the period from April 2005 to April 2006. After being cleaned with water and 70\% ethanol, skin samples were collected by friction of circular and sterile hair brushes against the posterior ventral region of the animals, on an area of no more than $10 \mathrm{~cm}$. After sample collection, the brushes were wrapped with the same aluminium foil used in the sterilization process. Within the next 24 hours, the material was streaked onto agar and incubated at $25^{\circ} \mathrm{C}$ to $30^{\circ} \mathrm{C}$ for up to four weeks. Micromorphology was used for mold identification purposes, and the process employed lactophenol cotton blue staining. Whenever an initial identification was not possible due to the absence of characteristic structures, the isolate would be picked onto Potato agar to stimulate the development of reproductive structures. Yeasts and yeast-like fungi were characterized by physiological routine assays and differential tests, such as chlamydoconidia production and germ tube tests, and also by cultivation in HiCrome Agar. Isolates that produced arthroconidia were classified into the genera Geotrichum or Trichosporon. A number of 501 isolates were obtained, of which 297 were molds and 204 yeasts. Among the molds, the hyalohyphomycetes prevailed with 211 isolates, followed by 53 pheohyphomycetes and 33 zygomycetes. Two hundred and four yeast samples were identified as Candida albicans and Trichosporon spp., in addition to other far less frequent species, such as $C$. glabrata.

Discussion: The varied range of species isolated from the skin of pigs in this study can be explained by a number of factors, such as type of management, swine farm installations and environmental variations. The diversity of the microbiota found in relation to other studies demonstrates the necessity of this kind of research, because knowledge of the prevailing microbiota in a determined region facilitates the evaluation of potential impacts of sporadic or emerging new fungal diseases in herds, particularly in immunosuppressed animals. The observation of 17 Scopulariopsis brevicaulis isolates is worth pointing out, as its presence, associated with environmental and host factors, may favor the infection of pigs and the clinical development of the Dermatitis in the species. Knowledge of the diversity of mycological agents that are in direct contact with healthy animals may assist the diagnosis of exotic etiologies, particularly in animals with immunosuppressive diseases, considering that these are being diagnosed in swine with an increasing frequency.
\end{abstract}

Keywords: fungal microbiota, pig skin, yeasts, hyalohyphomycetes, pheohyphomycetes, zygomycetes, Scopulariopsis brevicaulis, Pustular Psoriasiform Dermatitis.

Descritores: microbiota fúngica, pele de suínos, leveduras, hialohifomicetos, feohifomicetos, zigomicetos, Scopulariopsis brevicaulis, Dermatite Pustular Psoriaforme.

* Manuscript based on a thesis submitted by the senior author in partial fulfillment of requirements for the degree of Master of Veterinary Sciences from the Graduate Program in Veterinary Sciences-UFRGS ${ }^{1}$ Setor de Micologia, Faculdade de Veterinária (FaVet) \& Programa de Pósgraduação em Ciências Veterinárias (PPGCV), Universidade Federal do Rio Grande do Sul (UFRGS), Av. Bento Gonçalves no. 9090, Bairro Agronomia, CEP 91540-000 Porto Alegre, RS, Brasil. ²LAPEMI (Laboratório de Pesquisas Micológicas), Departamento de Microbiologia e Parasitologia, Universidade Federal de Santa Maria (UFSM), Santa Maria, RS, Brasil. ${ }^{3}$ Setor de Suínos, FaVet \& PPGCV-UFRGS. CORRESPONDÊNCIA: L. Ferreiro [laerte.ferreiro@ufrgs.br - FAX: + 55 (51) 3316-7305]. 


\section{INTRODUCTION}

Microbial agents are a potential risk, both in the dissemination of intra and interspecies diseases and in the production and preservation of foodstuffs destined to human and animal consumption $[4,16]$.

Fungi can be found in various substrates, foodstuffs (cereals, meat, milk, vegetables) and also in the skin, mucosae, respiratory and gastrointestinal tract of animals [32]. Furthermore, breeding in installations where a complete cleaning is not possible while animals are housed, in addition to contact with feces, will favor the multiplication and dissemination of the microbiota. Studies developed to evaluate the contamination of the environment and of grains used as foodstuff demonstrate the presence of several bacterial and mycological agents, even when the installations are undergoing a period of rest before refilling [19,35].

With the dissemination of immunosuppressive diseases in swine herds over the last years, the number of concomitant diseases caused by opportunist microorganisms is gradually increasing in literature, affecting different systems such as the integumentary, respiratory, and gastrointestinal [2,9,31]. In this new scenario, mycoses are being diagnosed with an increasing frequency, because an animal with impaired immunity often becomes unable to fight infection, even at low levels caused by direct or environmental contact.

Therefore, the objective of this study was to determine the microbiota of swine skin with no apparent lesions, in order to assess the degree of exposure to several potentially pathogenic agents.

\section{MATERIALS AND METHODS}

\section{Animals}

A number of 261 samples from healthy pigs were obtained for the study, originated from 11 swine farms located in six municipalities of the State of Rio Grande do Sul, in Southern Brazil, in the period from April 2005 to April 2006.

\section{Collection of Samples}

The material was collected by means of friction of circular and sterile hair brushes against the posterior ventral region of the animals, on an area of no more than $10 \mathrm{~cm}$. The brushes were sterilized by overnight exposure to ultraviolet light. A negative control of the incubation was made after each brush sterilization process.

The samples were collected after the skin was cleaned with water and $70 \%$ ethanol. After collection of the samples, the brushes were wrapped with the same aluminium foil used in the sterilization process. The material was cultured within less than 24 hours.

\section{Fungal Isolation}

The material was streaked onto Sabouraud's dextrose agar with $0.5 \mathrm{~g} / \mathrm{L}$ chloramphenicol and incubated for a period of up to four weeks at a temperature of $25^{\circ} \mathrm{C}$ to $30^{\circ} \mathrm{C}[14,22]$.

\subsection{Mold Identification}

Micromorphology was made employing lactophenol cotton blue staining. Whenever an initial identification was not possible due to the absence of characteristic structures, the isolate would be picked onto Potato agar to stimulate the development of reproductive structures [14,21,33].

\subsection{Identification of Yeasts and Yeast-like Fungi}

The yeasts were characterized through physiological routine assays [3,38] and differential tests, such as chlamydoconidia production and germ tube tests [21] and through cultivation in HiCrome Agar. Isolates producing arthroconidia were classified in the genera Geotrichum or Trichosporon.

\section{RESULTS}

A number of 501 isolates were obtained among the 261 samples, of which 297 (59\%) were molds and $204(41 \%)$ yeasts. Among the molds, the hyalohyphomycetes prevailed with 211 (71\%) isolates (genera Penicillium, Aspergillus, Geotrichum, Scopulariopsis and Fusarium), followed by 53 (18\%) pheohyphomycetes (genera Cladosporium, Curvularia, Alternaria and Aerobasidium) and 33 (11\%) zygomycetes (Mucor e Absidia) (Table 1). The 204 yeast specimens were identified as being Candida spp. (45\%), Candida albicans (35.3\%), Trichosporon spp. (10.7\%), Candida krusei (2.4\%), C. tropicalis (2\%), Candida parapsilosis (1.5\%) in addition to other far less frequent species, such as C. glabrata, Rhodotorula sp., Candida famata and Pichia ohmeri (Table 2). 


\section{DISCUSSION}

Researches to observe the normal microbiota of different animal species have been developed $[1,18,25]$. This is of major importance for the control of potential infection risks, particularly the ones associated with species under confinement, where an unbalance of the environmental microbiota may influence the animal-environment interaction, with the consequent development of diseases.

Molds and yeasts are widely distributed in nature, being found in the terrestrial environment, aquatic environment or as a part of the anemophile microbiota. Several studies identifying the fungal microbiota, both in installations and in swine food, have been already published [12,13,19,30,35]. Absidia spp., Alternaria spp., Aspergillus flavus, Cladosporium spp., Fusarium spp., Penicillium spp., Rhizopus spp., and Scopulariopsis spp. have been already identified in swine installations [13,19].

In the present study, $211(71 \%)$ hyalohyphomycetes (genera Aspergillus, Penicillium, Geotrichum, and Fusarium) have been isolated. Researches involving foodstuffs used in swine food, particularly corn, indicate the isolation of Aspergillus spp., Penicillium spp., Fusarium spp., Alternaria spp., and Cladosporium spp. [12,30,35]. The most

Table 1. Diversity of molds isolated from the skin of healthy pigs from swine farms located in municipalities of the State of Rio Grande do Sul, Southern Brazil, during one year (April 2005 to April 2006).

\begin{tabular}{|c|c|c|c|}
\hline Molds & Number (\%) & Isolates & Number (\%) \\
\hline \multirow[t]{10}{*}{ hyalohyphomycetes } & $211(71.0)$ & & \\
\hline & & Penicillium spp. & $52(17.7)$ \\
\hline & & Aspergillus flavus & $29(9.7)$ \\
\hline & & A. fumigatus & $21(7.0)$ \\
\hline & & Geotrichum spp. & $21(7.0)$ \\
\hline & & Scopulariopsis brevicaulis & $17(5.7)$ \\
\hline & & Aspergillus spp. & $8(2.7)$ \\
\hline & & Fusarium spp. & $6(2.0)$ \\
\hline & & Aspergillus niger & $2(0.7)$ \\
\hline & & Mycelia sterilia & $55(18.5)$ \\
\hline \multirow[t]{5}{*}{ pheohyphomycetes } & $53(18.0)$ & & \\
\hline & & Cladosporium spp. & $46(15.5)$ \\
\hline & & Curvularia spp. & $3(1.0)$ \\
\hline & & Alternaria spp. & $3(1.0)$ \\
\hline & & Aerobasidium sp. & $1(0.3)$ \\
\hline \multirow[t]{4}{*}{ zygomycetes } & $33(11.0)$ & & \\
\hline & & Mисоr spp. & $21(7.0)$ \\
\hline & & Absidia spp. & $4(1.3)$ \\
\hline & & Not identified & $8(2.7)$ \\
\hline
\end{tabular}


frequently genus found among the hyalohyphomycetes was Aspergillus spp. (20.1\%), with 60 isolates.

The observation of 17 Scopulariopsis brevicaulis isolates must be pointed out as the presence of this agent, associated to environmental and hostrelated factors, may favor the infection and clinical development of the Porcine Pustular Psoriasiform Dermatitis [6,8,26,27]. Additionally, S. brevicaulis could also be the agent of dermatomycoses in humans and animals $[11,23,24]$.

Among 53 (18\%) pheohyphomycetes, the genus Cladosporium was observed with 46 isolates. Pheohyphomycetes are associated with opportunist infections that are being found with an increasing frequency in human and animal pathology; the most frequent clinical form involves cutaneous and/or subcutaneous tissues, but dissemination to several organs may occur in animals with an impaired immune system $[7,15,36]$. The presence of melanin in their cell walls may be a virulence factor for these fungi. Human cases of endocarditis are mostly reported on bioprosthetic valves, in particular those of porcine origin [28].

With regards to zygomycetes, the genus Mucor has widely prevailed. This is an omnipresent fungus, but that is little associated with diseases, both in animals and in humans. These fungi have an acknowledged potential to infect a wider variety of organisms in comparison to other filamentous fungi [29]. Zygomycoses are diseases of an opportunist nature, in which the degree of resistance of the host, the amount of inocula and the virulence factors of the microorganism are important characteristics for the development of the clinical picture. The occurrence of gastric zygomycosis in a pig affected by postweaning multisystemic wasting syndrome has been recently described [34]. This mycosis has been already described in swine, equines, bovines, ovine, and dogs [32].

With regard to yeast, Candida albicans is the species that has been most frequently isolated and

Table 2. Diversity of yeasts isolated from the skin of healthy pigs from swine farms located in municipalities of the State of Rio Grande do Sul, Southern Brazil, during one year (April 2005 to April 2006).

\begin{tabular}{cccc}
\hline Genera & Number (\%) & Isolates & Number $(\%)$ \\
\hline Candida & $179(87.8)$ & & \\
& & Candida albicans & $72(35.3)$ \\
& C. krusei & $5(2.4)$ \\
& C. tropicalis & $4(2.0)$ \\
& C. parapsilosis & $3(1.5)$ \\
& C. glabrata & $2(1.0)$ \\
& C. famata & $1(0.5)$ \\
& Candida spp. & $92(45.1)$
\end{tabular}

Trichosporon $22(10.7)$

Trichosporon spp. $22(10.7)$

Rhodotorula $2(1.0)$

Rhodotorula spp. $\quad 2(1.0)$

Pichia $\quad 1(0.5)$

Pichia ohmeri $\quad 1(0.5)$ 
described, both in human and veterinary medicine. The infections caused by the development of this species are usually not regarded as opportunist due to their endogenous nature, as the genus Candida is a skin, mucous and digestive tract commensal of mammals and birds [37]. In this study, C. albicans was found most frequently, representing $35.3 \%$ from a total of 204 yeast specimens. Its presence may be influenced by a reduced competition among agents, ease of contamination from matrices due to the successive contact with their feces, continuous use of medication, use of a number of stressing managing techniques (dental wear, vaccinations, docking, among others), which could allow its colonization and establishment of the disease [13,19,31,37,39].

Candidosis in swine can occur when the defenses of the host are reduced. The disease has been observed in piglets fed with food leftovers and which are kept under precarious sanitary conditions, and it can affect up to $40 \%$ of the herd [6]. The disease has been reported in pigs bred both in complex commercial systems and in extensive systems [9,39]. These animals, after being affected by viral diseases, presented a clinical picture of candidosis, demonstrating the importance of this fungal agent in the production chain.
The existence of eventual errors in some production segments, such as a high population index, sudden temperature variations and an increase in the environmental humidity rate, among other factors, generally allows the occurrence of diseases. Such situations, associated with the presence of immunosuppressive agents, contribute to decrease the resistance of the animals, leaving them susceptible to the action of several microorganisms [25].

Zygomycetes, Aspergillus and Candida spp., for instance, can be considered nowadays potential pathogens in swine pathology, after the onset of immunosuppressive diseases in herds from various continents [10,31,34,39].

\section{CONCLUSIONS}

The varied range of species isolated from skin of pigs, as shown in this study, can be explained by a combination of factors, such as management type, swine farm installations and environmental variations. The diversity of the microbiota found in relation to other studies demonstrates the necessity for this kind of study, as knowledge of the prevailing microbiota in a determined area facilitates the evaluation of potential impacts of sporadic or emerging new fungal diseases in herds, particularly in immunosuppressed animals.

\section{REFERENCES}

1 Aho R. 1983. Saprophytic fungi isolated from the hair of domestic and laboratory animals with suspected dermatophytosis. Mycopathologia. 83 (2): 65-73.

2 Barcellos D.E.S.N. \& Sobestiansky J. 2003. Atlas de Doenças de Suínos. Goiânia: Art 3, p. 47.

3 Barnett J.A, Payne R.W. \& Yarrow D. 2000. Yeasts, characteristics and identification. 4th edn. Cambridge: Cambridge University Press, $811 \mathrm{p}$.

4 Bláha J., Jíếnská E., Vesely D. \& Jelínek R. 1990. The effect of moulds on the nutritional value of wheat. Animal Feed Science and Technology. 28: 315-324.

5 Cabañes F.J., Abarca M.L., Bragulat M.R. \& Castellá G. 1996. Seasonal study of the fungal biota of the fur of dogs. Mycopathologia. 133 (1): 1-7.

6 Cameron R.D.A. 1999. Diseases of the skin. In: Straw B., D'Allaire S., Mengeling W.L. \& Taylor D.J. (Eds). Diseases of Swine. 8th ed. Ames: Iowa State University Press, p. 941-958.

7 Chabasse D. 2002. Les Phaéohyphomycètes agents de Phaéohyphomycoses: Des champignons émergents. Journal de Mycologie Médicale. 12: 65-85.

8 Corcoran C.J. 1964. Pityriasis Rosea in Pigs. The Veterinary Record. 76: 1407-1409.

9CorrêaA.M.R., Zlotowski P., Rozza D. B., Borba M.R., Leal J. S., Cruz C.E.F.C. \& Driemeier D. 2006. Postwaning multisystemic wasting syndrome in farmed wild boarws (Sus scrofa) in Rio Grande do Sul. Pesquisa Veterinária Brasileira. 26(3): 154156.

10 Corrêa W.M., Corrêa C.N.M. 1992. Enfermidades Infecciosas dos Mamíferos Domésticos. In: Outras Micoses, Prototecose e Micotoxicoses. 2.ed. Rio de Janeiro: Médica e Científica, p. 461.

11 Cox N.H. \& Irving B. 1993. Cutaneous "ringworm" lesions of Scopulariopsis brevicaulis. British Journal of Dermatology. 129 (6): 726-728. 
Carregaro F.B., Spanamberg A., Sanches E.M.C., Argenta J.S., Pereira D.I.B., Zanette R., Santurio J.M., Barcellos D.E.S.N. \&

12 Dilkin P., Mallmann C.A., Santurio J.M. \& Hickmann J.L. 2000. Classificação Macroscópica, Identificação da Microbiota Fúngica e Produção de Aflatoxinas em Híbridos de Milho. Ciência Rural. 30 (1): 137-141.

13 Donham K.J., Scallon L.J., Pependorf W., Treuhaft M.W. \& Roberts R.C. 1986. Characterization of dusts collected from swine confinement buildings. American Industrial Hygiene Association Journal. 47 (7): 404-410.

14 Ellis D., Davis S., Alexiou H., Handke R. \& Bartley R. 2007. Descriptions of Medical Fungi. 2nd ed. Adelaide: Nexus Print Solutions, 198p.

15 Ferreiro L., Spanamberg A., Borba M.R., Cavallini Sanches E.M., Roehe C., Santurio J.M. \& Chermette R. 2007. Feohifomicoses: infecções micóticas emergentes. Acta Scientiae Veterinariae. 35 (Supl 2): s239-s241.

16 Filtenborg O., Frisvad J.C. \& Thrane U. 1996. Moulds in food spoilage. International Journal of Food Microbiology. 33 (1): 85-102.

17 Gründer S., Mayser P., Redmann T. \& Kaleta E.F. 2005. Mycological examinations on the fungal flora of the chicken comb. Mycoses. 48 (2): 114-119.

18 Ishikawa M.M., Lucas R., Larsson C.E., Gambale W. \& Fernandes W.R. 1996. Isolamento e identificação da microbiota fúngica e de dermatófitos da pele de eqüinos hígidos e daqueles afetados por dermatofitose. Brazilian Journal of Veterinary Research and Animal Science. 33 (3): 170-175.

19 Martin W.T., Zhang Y., Willson P., Archer T.P., Kinahan C., Barber E.M. 1996. Bacterial and fungal flora of dust deposits in a pig building. Occupational and Environmental Medicine. 53 (3): 484-487.

20 Moriello K. \& DeBoer D.J. 1991. Fungal flora of the coat of pet cats. American Journal of Veterinary Research. 52 (4): $602-$ 606.

21 Neufeld P.M. 1999. Manual de Micologia Médica: técnicas básicas de diagnóstico. Rio de Janeiro: Ed. Programa Nacional de Controle de Qualidade, 240p.

22 Paixão G.C. \& Sidrim J.J.C. 1999. Meios de cultura usados em micologia. In: Sidrim J.J.C. \& Moreira J.L.B. Fundamentos Clínicos e Laboratoriais da Micologia Médica. Rio de Janeiro: Guanabara Koogan, p. 247-254.

23 Paula C.R, Costa E.O., Pires M.F.C., Coutinho S.D., Carvalho V.M., Castilho W. \& Moral M.S. 1987. Scopulariopsis brevicaulis: agente etiológico de dematose em cães e eqüinos. Revista Microbiologica. 18: 366-370.

24 Pires D.C., Del Bianchi M., Portugal M.A.S.C., Hipólito M. 1989. Dermatomicose em Camundongos (Mus Musculus) de Biotério Devida a Scopulariopsis sp. Biológico. 55: 11-12.

25 Pires M.F.C, Coutinho S.D, Purchio A., Kipnis T.L. \& Noronha M. 1986. Microbiota Fúngica na Pelagem de Camundongos de 23 Linhagens Isogênicas e Congênicas Mantidos em biotério de Criação. Revista da Faculdade de Medicina Veterinária e Zootecnia da Universidade de São Paulo. 23: 139-144.

26 Portugal M.A.S.C., Proba G.A., Saliba A.M. \& Farinha F.B. 1982. Pitiríase rosada dos suínos no Estado de São Paulo. Biológico. 48: 265-268.

27 Purchio A., Machado A., Gambale W., Paula C.R. \& Mariano M. 1980. Scopulariopsis brevicaulis: a possible etiologic agent of pityriasis rosea in piglets. Mycoses. 23: 104-111.

28 Revankar S.G., Patterson J.E., Sutton D.A., Pullen R. \& Rinaldi M.G. 2002. Disseminated phaeohyphomycosis: Review of an Emerging Mycosis. Clinical Infectious Diseases. 34 (4): 467-476.

29 Richardson M. 2009. The ecology of Zygomycetes and its impact on environmental exposure. Clinical Microbiology and Infection. 15 (s5): 2-9.

30 Rodríguez-Amaya D.B. \& Sabino M. 2002. Micotoxin research in Brazil: The Last Decade in Review. Brazilian Journal of Microbiology. 33 (1): 1-11.

31 Segalés J., Domingo M., Collell M., Jensen H.E. \& Blanco J.L. 2003. Pulmonary Aspergilosis in a Post-Weaning Multisystemic Wastein Syndrome (PMWS) Affected Pig. The Pig Journal. 52: 41-47.

32 Sidrim J.J.C. \& Rocha M.F.G. 2004. Micologia Médica à Luz de Autores Contemporâneos. Rio de Janeiro: Guanabara Koogan, 380p.

33 ST-Germain G. \& Summerbell L. 1996. Identifying filamentous fungi. A Clinical Laboratory Handbook. Belmont: Star Publishing Company, 314p.

34 Szeredi L. \& Szentirmai C. 2008. Gastric zygomycosis in a pig affected with postweaning multisystemic wasting syndrome - Case report. Acta Veterinaria Hungarica. 56: 207-213.

35 Tanaka M.A.S., Maeda J.A. \& Plazas I.H.A.Z. 2001. Microflora Fúngica de Sementes de Milho em Ambientes de Armazenamento. Scientia Agrícola. 58 (3): 501-508. 
36 Urbini R. 2000. Les Phaeohyphomycoses Animales. Revue bibliographique. 100f. Nantes, França. Tese (Thése de Docteur Vétérinaire) - École Nationale Vétérinaire de Nantes.

37 Van Uden N., Sousa L.D. \& Farinha M. 1958. On the intestinal yeast flora of Horses, Sheep, Goats and swine. Journal of General Microbiology. 19: 435-445.

38 Yarrow D. 1998. Methods for the isolation, maintenance, and identification of yeasts. In: Kurtzman C.P. \& Fell J.W. (Eds). The yeasts, a taxonomic study. Amsterdam: Elsevier Science, p. 77-100.

39 Zlotowski P., Rozza B. D., Pescador C. A., Barcellos D.E., Ferreiro L., Sanches E.M.C. \& Driemeier D. 2006. Mucocutaneus candidiasis in two pigs with potsweaning multisystemic wasting syndrome. The Veterinary Journal. 171: 566569. 
